\title{
Occupation-specific wage returns: shedding light on differentials between employees with a VET degree either with or without an Abitur
}

\author{
Anett Friedrich and Sandra Hirtz (1)
}

${ }^{*}$ Correspondence:

Hirtz@bibb.de

Federal Institute

for Vocational Education

and Training (BIBB),

Robert-Schuman-Platz 3,

53175 Bonn, Germany

\begin{abstract}
This study seeks to reveal the heterogeneity in occupation-specific wage returns among graduates of the German vocational education and training (VET) system. We distinguish between VET graduates with and without a higher education entrance certificate (i.e. an Abitur). To implement our hierarchical multi-level analyses, we exploit the latest wave of the BIBB/BAuA Employment Survey from 2018. By estimating occupation-specific wage returns, we reveal gaps between VET graduates with and without an Abitur. Additionally, we analyse several occupational characteristics to show how they contribute to the gaps in wage returns between our study groups. Our results show that employees combining an Abitur with a VET degree achieve higher wage returns than those VET graduates without an Abitur across all occupations. Employees holding a VET degree without an Abitur display greater inequality of occupation-specific wage returns. Among the occupational characteristics, task composition is the main driver of the differences in wage returns.
\end{abstract}

Keywords: VET, Occupation-specific wage returns to education, Germany, Abitur, School-leaving certificate, Multi-level analysis, Inequality of wage returns, Tasks, Occupational specificity

\section{Introduction}

Educational attainments and occupations play a major role for employees' remuneration in Germany. Driven by technological change, the demand for higher skills and thus higher qualifications within occupations has increased. Simultaneously, the educational expansion has enhanced the average level of school-leaving certificates. The demand for and the supply of qualifications affect the remuneration of employees in modern labour markets. Technological and educational developments raise the question of the relevance of school-leaving certificates. Our paper aims to detect whether different combinations of qualifications manifest in various wage returns to education across occupations. 
The German education system is highly stratified and standardised (Allmendinger 1989 ) and is rather special in the international context. The schism between vocational education and training (VET) and the higher education system (Powell and Solga 2011) induces relatively low participation in tertiary education. Typically, by obtaining either a secondary school-leaving certificate (10 years of schooling) or an Abitur (12/13 years of schooling), young people commit to either VET or higher education. Our research focus lies on examining the combination of different school-leaving certificates (i.e. with or without an Abitur) with a VET degree. This differentiation of VET graduates based on their previous schooling delineates the key characteristic that distinguishes our analysis groups.

From previous research, we know that differences in wage returns between educational attainments exist (e.g. Friedrich and Horn 2018). Plenty of studies deal with differences in wage returns between (applied) university and VET graduates. However, differences in remuneration within the VET qualification depending on previous schooling play a subordinate role in the literature, as graduates within the VET system formally have the same qualification level. Prior studies focused on the access to the VET system when examining the differences between school-leaving certificates. For example, Beicht and Walden (2018) show that school leavers with an Abitur have an advantageous transition to the VET system. So far, research rarely deals with the question if such advantages of an Abitur also manifest during employment or if the VET degree abrogates the effect of schooling. Moreover, the literature documents well the wage inequality induced by varying wage returns to education (e.g. Giesecke and Verwiebe 2009) and by occupations (e.g. Haupt and Ebner 2020). Again, we do not know whether an Abitur attenuates or intensifies inequality in wage returns to education.

In addition to educational attainments, occupations are a key aspect of current research on wages and wage returns (e.g. Bol and Weeden 2015; Haupt 2016b). Previous empirical findings indicate that wages vary across occupations even within the same level of education (e.g. Blien and Hong Van 2010; Stüber 2016). However, an investigation of whether previous schooling drives this variation is still pending. Moreover, we know little about occupational characteristics shaping the heterogeneity of wage returns to education.

Our study focuses on the core element of the German education system, the VET system, whose graduates cover about two third of the employees. We distinguishes between two groups of employees with a VET degree: those with an Abitur and those without an Abitur. This distinction has special importance in light of the rising share of school leavers with an Abitur. We aim to disentangle the heterogeneity of the occupationspecific wage returns of employees with a VET degree either with or without an Abitur descriptively.

We use the latest wave of the BIBB/BAuA-Employment Survey from 2018 (Hall et al. 2020). These current data allow us to identify wage returns at the individual level. Furthermore, the high number of observations (approximately 20,000) enables us to consider the current occupational level (3-digit level of the KldB 2010). We conceptualise hierarchical multi-level analyses of German employees between the ages of 18 and 65 . To inspect the wage returns to education for each working occupation, we estimate occupation-specific slopes for VET graduates with and without an Abitur. 
Calculating the occupation-specific wage returns for VET graduates with and without an Abitur separately, contributes to the understanding of the link between wages and occupations. We unveil that wage returns to education for VET graduates differentiate across occupations.

Further, our study fosters the discussion about wage inequality by exploring variance in occupation-specific wage returns among VET graduates. Applying different inequality measures, reveals for VET graduates without an Abitur higher inequality of occupationspecific wage returns than for VET graduates with an Abitur.

Finally, to support the understanding of the mechanisms driving the gaps in wage returns across occupations, we analyse occupational characteristics. These analyses show that the share of performed tasks, the share of employees with higher education degrees and occupational specificity within an occupation turn out to shape the gap in wage returns to education between our study groups.

We contribute to the existing literature on wage returns to education by evaluating whether VET certificates have a greater influence on wages than previous schooling. By examining wage returns for both VET graduate groups, we address the important question of whether investments in more years of schooling pay off. In this way, we scrutinise the signaling power of degrees and the exploitation opportunities of human capital accumulated during previous schooling. Our results suggest that the years of schooling relate to a wage premium for employees with a VET degree.

The article proceeds as follows: First, we provide a short overview about the German education and VET system. Afterwards, we sketch the state of research succeeded by the theoretical considerations to derive hypotheses. The subsequent section outlines our analytic approach, the used data and the operationalisation of our key variables. In the following chapter, we present and relate our empirical findings to our hypotheses. Finally, we draw the conclusion and give impulses for further research.

\section{Background}

\section{German education and the VET system}

A pronounced path dependency characterises the route through the German education system. Generally, one can distinguish between two tracks: first, a vocational track including the VET system and, second, an academic track covering the higher education system (cf. Figure 1). After a student pursues one track, switching from the academic to the vocational track is possible but rather complicated and rarely done.

At a very early age (in most federal states, after fourth grade, at the age of ten), pupils (and their parents) need to choose between the two main educational tracks. Secondary schools (lower or intermediate) provide students on the first track with the given certificates and prepare them to embark on apprenticeships. The second track incorporates gymnasiums and all other schools qualifying pupils for higher education. After 12/13 years of schooling, pupils receive the highest German school-leaving certificate, namely, the Abitur, which opens the track into the higher education system. Nevertheless, in Germany (and uncommonly, from an international perspective), school leavers with a higher education entrance certificate can also decide to take the 'atypical' path into the VET system (cf. Figure 1). Hence, school leavers with or without an Abitur 


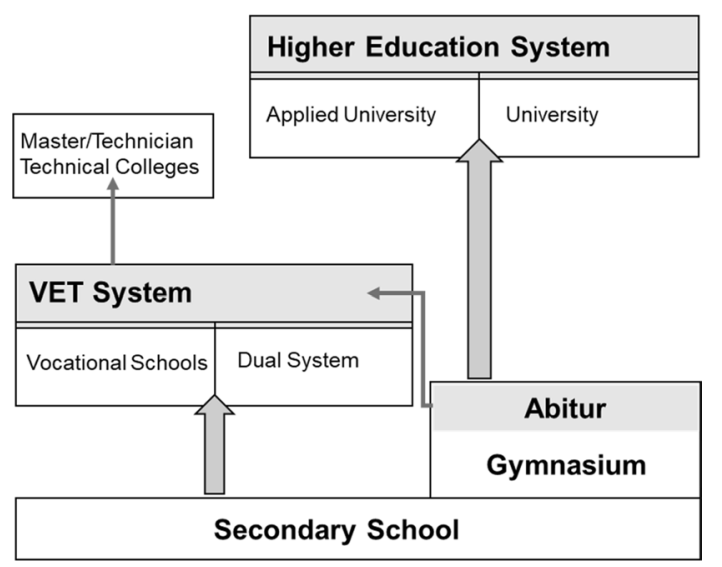

Fig. 1 The German education system and its educational tracks (Source: Own image)

compete for training places, and school leavers with an Abitur displace those without an Abitur (Beicht and Walden 2018).

The German VET system consists of two parts leading to a qualified vocational degree: the dual system and the full-time vocational school system. ${ }^{1}$ With approximately $49 \%$ of the apprentices, the dual system dominates the VET system (reference year: 2017) (Bildungsberichterstattung 2018, p. 128). Formally, the transition into the dual system is not restricted to a specific school-leaving certificate. Nevertheless, firms act as gatekeepers for dual apprenticeships and may define a minimum school-leaving certificate as an entrance requirement. The training lasts approximately 2 to 3.5 years ( 3 years on average), during which time the apprentices are paid by the firms. The training phase takes place at two training venues. Apprentices learn and work within their training firm and attend an additional state-run vocational school. The curriculum and exams of the dual system are highly standardised throughout Germany. Currently, the dual system covers 324 training occupations.

The full-time vocational school system covers approximately $22 \%$ of the apprentices in the VET system (reference year: 2017) (Bildungsberichterstattung 2018, p. 128). In contrast to the dual system, vocational schools mostly require at least an intermediate secondary school-leaving certificate of students wishing to start training. Apprentices are not paid; rather, depending on the apprenticeship, they may have to pay fees. During their training, apprentices spend most of their time in vocational schools, complemented by time in internships to gain practical experience. The curriculum and exams are very heterogeneous and vary across the 16 federal states of Germany. The full-time school system covers mostly health-care and nurturing occupations.

The school-leaving certificate strongly influences the transition into the VET system. Most of the young people entering the VET system hold an intermediate school-leaving certificate, while the share of youths with an Abitur rose from 20\% in 2009 to $29 \%$ in 2017 (Bundesinstitut für Berufsbildung [BIBB] 2019, p. 141). In contrast, the share of

\footnotetext{
${ }^{1}$ A third part of the German VET system is the transition system, which prepares young people for further education without leading to a qualified degree. Approximately $29 \%$ of the young people in the VET system are in this sector (Autorengruppe Bildungsberichterstattung 2018, p. 128).
} 
apprentices with a lower school-leaving certificate shrank from 33\% in 2009 to $25 \%$ in 2017 (ibid.) and their difficulties in finding an apprenticeship increased (e.g. Kleinert and Jacob 2012).

\section{Combining academic and vocational education}

Instead of being a uniform system, as is often assumed, the German VET system is strongly vertically stratified, particularly with regard to the school-leaving certificate (e.g. Protsch and Solga 2015). School graduates with or without an Abitur select themselves into different occupations and face diverging access barriers to training positions (e.g. Protsch and Solga 2015; Beicht and Walden 2018). Distinguishing between VET graduates with and without an Abitur promises to offer valuable insights into heterogeneity within the VET system.

As stated before, a peculiarity of the German education system is that school leavers with a higher education entrance certificate may decide to enter the VET system. A substantial fraction of Abitur holders start an apprenticeship rather than going to university. The VET degree marks an attractive alternative to academic education instead of being a stopgap solution.

School leavers with an Abitur also combine vocational and higher education. This combination, known as double qualification, is a particular feature of the German education system (Pilz 2009a). An entire strand of literature deals with why Abitur holders mix educational paths and decide to embark on an apprenticeship before going to university (e.g. Jacob et al. 2013; Pilz 2009a, b). Empirical investigations demonstrate that the Abitur grade significantly affects the likelihood of double qualification (e.g. Jacob et al. 2013). Further, the Abitur grade serves as an indicator to cushion the risk of failure (Bellmann and Janik 2010). From an economic point of view, double qualifications lead to higher individual investment costs because students stay much longer in the education system and enter the labour market less quickly than those who directly go to university (Bellmann and Janik 2010). However, Tuor and Backes-Gellner (2010) demonstrate that combining different types of education is a worthwhile strategy. In contrast to purely academically educated employees, those with mixed educational paths generate higher earnings.

Varying wage returns between VET graduates with or without an Abitur across occupations Current findings empirically evince that wage returns vary within educational attainment levels and across occupations (e.g. Haupt 2016b; Blien and Hong Van 2010). We know from previous research that apart from the VET degree itself, the school-leaving certificate has a substantive impact on access to occupations and the labour market (e.g. Beicht and Walden 2018). Since occupations display various wage effects (Göggel and Zwick 2012), distinguishing between employees with a VET degree with or without an Abitur within occupations is reasonable.

In the following, we discuss approaches capable of explaining theoretically both the differences in wage returns between our study groups and the role of occupations in driving these differences. The literature provides several theoretical approaches that attempt to explain why employees with diverse educational attainments obtain varying wage returns, including $\mathrm{HCT}$, credentialism and signaling theory. Since these 
frameworks neglect the role of occupation-specific effects in wage returns, we also refer to the task approach as an explanation for the heterogeneity in wage returns to education across occupations.

First, according to HCT, the more people invest in their education, the higher is their productivity and their resulting wage (Becker 1964). This assumption implies that employees who undertake equal educational investments are comparably productive and rewarded equally. Hence, we presume that graduates with an Abitur, who formally hold an equal level of educational attainment to other VET holders but who have invested two to three years more in schooling, should achieve higher wage returns.

According to signaling theory (Spence 1973), employees' educational attainment signals their productivity. This approach argues that observable characteristics such as educational attainment help employers evaluate employees' potential productivity, making it reasonable for employees to invest in their signaling power. Years of schooling and the school-leaving certificate could both function as signals. Consequently, we derive that VET graduates with an Abitur signal higher productivity due to their two or three additional years of schooling (Beicht and Walden 2018). In this light, VET graduates with an Abitur should face higher average wage returns to education than VET graduates without an Abitur.

Reasoning that Abitur holders have accumulated more human capital and that years of schooling function as a signal, we suggest the following first hypothesis:

Employees with a VET degree and an additional Abitur achieve higher average wage returns to education than employees with a VET degree without an Abitur (H1a)

Nonetheless, in the context of signaling, one can also argue that employees with a VET degree signal the same productivity to employers regardless of their years of schooling. The VET degree, not the school-leaving certificate, could function as the signal of productivity and sets the wage potential. Consequently, VET graduates with or without an Abitur should achieve comparable wage returns.

Further, credentialism stresses the power of educational certificates for labour market outcomes. Credentials (i.e. certificates) determine employees' access to occupations and have a gatekeeping function. Certificates establish which occupations employees can pursue and affect their income possibilities (Collins 1979). The VET degree denotes a typical German credential, and its relevance considerably exceeds that of the Abitur as the highest school-leaving certificate. Collins (1979) emphasises 'the non-productive element of schooling' (Barone and van de Werfhorst 2011, p. 487). Based on this statement, our position complies with the idea that ' $[\mathrm{c}]$ entral to the credentialism theory is that education effects on earnings are mainly manifested through the regulated access to occupations' (ibid.). According to credentialism, the VET degree should outweigh the wage-increasing effect of previous schooling. Hence, VET graduates with or without an Abitur should achieve comparable average wage returns.

As an alternative hypothesis to $H 1 a$, we assume the VET degree to be the decisive certificate affecting wage returns and to function as a crucial signal, regardless of previous years of schooling. Our next hypothesis reads as follows:

Employees with a VET degree and an additional Abitur achieve the same average wage returns to education as employees with a VET degree without an Abitur (H1b) 
Second, we take into account that wage returns to education for employees with a VET degree vary across occupations. The task approach classifies jobs according to the skills required and tasks performed (Acemoglu and Autor 2011). The allocation of skills to tasks determines employees' wages (Autor 2013). Autor et al. (2003) distinguish five task types, namely, routine cognitive, routine manual and non-routine manual, analytic and interactive tasks. Occupations are 'task bundles', with each occupation comprising a different proportion of tasks.

Empirical studies for Germany reveal that the occupation-inherent task composition influences wages (e.g. Antonczyk et al. 2018). A high share of routine tasks comes along with wage penalties (Bachmann et al. 2018). Conversely, non-routine tasks are associated with wage premiums (Rohrbach-Schmidt 2019). Theoretically, every employee can perform all tasks; nonetheless, tasks vary considerably by employees' educational level. Those with higher educational attainment have a higher comparative advantage and higher productivity in performing non-routine tasks (Autor 2013). The composition of tasks varies not only between but also within occupations (Autor and Handel 2013; Rohrbach-Schmidt 2019).

Even though VET graduates with or without an Abitur hold the same qualification level, they differ in terms of their skills acquired at school. Reiss et al. (2019) show that students attending a gymnasium show higher competencies in reading, arithmetic and natural sciences than students attending secondary school. The two to three years of additional schooling equip VET graduates with an Abitur with further human capital (Schneider 2008), empowering them to complete analytic and interactive tasks. According to the task approach, we deduce that being more productive in performing analytic and interactive tasks should raise wage returns. Hence, VET graduates with an Abitur should achieve higher returns. This line of argumentation entails our second hypothesis:

Obtaining an Abitur in combination with a VET degree results in higher occupationspecific wage returns ( $\mathrm{H} 2)$

Third, the already-mentioned higher competencies in reading, arithmetic and natural sciences of students attending a gymnasium come with a lower variance in the respective competencies than that of students attending secondary school (Reiss et al. 2019). Hence, a secondary degree is associated with a wider distribution of competencies. Linking back to tasks, we infer that the heterogeneity of competencies acquired through previous schooling entails a wider distribution of tasks and with it a wider range of wage returns for employees with a VET degree but without an Abitur. In contrast, Abitur holders are more homogenous concerning their competencies and tasks, leading to our third hypothesis:

Employees with a VET degree and an Abitur experience lower wage inequality across occupations than those without an Abitur (H3)

So far, we have proposed hypotheses for why we expect to find differences in the average and occupation-specific wage returns of VET graduates with or without an Abitur. In the next step, we reveal the influence of occupations by specifying five occupational characteristics impacting occupation-specific wage returns. 


\section{Which factors contribute to variance in occupation-specific wage returns?}

Having argued that wage returns differ between employees holding a VET degree and across occupations, we forth disentangle the occupational characteristics shaping these differences. Controlling for occupational characteristics should result in changing wage gaps between employees with a VET degree with and without an Abitur. These analyses help to clarify why occupation-specific wage returns differ. We select characteristics serving as reliable proxies for heterogeneity in wage returns and derive five further hypotheses.

Occupational wage-setting mechanisms do not necessarily correspond to neoclassical labour market rules. For Germany, Haupt (2016a) demonstrates that licensed occupations, with their fixed skill requirements, imply a lower wage variance. Licensing restricts opportunities to practice certain occupations - mostly health care, teaching and legal occupations as well as those in the police and armed forces - to those who have obtained an occupational license. Accordingly, we argue that differences in wage returns between holders of a VET degree with or without an Abitur are likely to be smaller in licensed occupations, summarised in our fourth hypothesis:

The gap between the occupation-specific wage returns of VET graduates with and without an Abitur increases when we control for licensing (H4)

As stated before, occupations serve as a proxy for tasks, whereas tasks are reflected in employees' wages. Unless all VET graduates have the same qualification level, they differ in terms of the skills acquired through their previous schooling (Reiss et al. 2019). VET graduates holding an Abitur have a comparative advantage in performing analytic and interactive tasks. Consequently, they are more likely to perform non-routine tasks and achieve higher wage returns. The argument that VET graduates are likely to complete different tasks within the same occupation depending on their schooling-leaving certificate leads to our fifth hypothesis:

The gap between the occupation-specific wage returns of VET graduates with and without an Abitur narrows if we control for job tasks (H5)

From previous literature, we know that wages differ significantly according to gender and the gender composition of occupations (e.g. Blau and Kahn 2017). In Germany, we find clear gender segregation, with occupations being traditionally male- or femaledominated (Finke et al. 2017). Designated as the gender pay gap, differences in wages vary across occupations with different gender compositions (Wrohlich and Zucco 2017). In occupations mainly held by women, average wages are much lower than those in male-dominated occupations (Hinz and Gartner 2005). Employees working in female occupations experience similar wage penalties, while they earn higher wages in male occupations (Busch 2013). Women tend to qualify more often in the full-time vocational school system, which is associated with lower signaling power despite the higher entrance requirements (at least an intermediate secondary school-leaving certificate) (Hall 2012). We argue that women are more likely to work in occupations with higher school-leaving requirements (i.e. VET2 occupations) but generate lower wage returns. Accordingly, we posit the sixth hypothesis:

The gap between the occupation-specific wage returns of VET graduates with and without an Abitur increases if we control for the share of women working in the occupation (H6) 
According to queuing theory (Thurow 1975), employers sort jobseekers based on educational information to predict their potential trainability. Hiring represents an uncertain investment, which causes employers to choose applicants with the lowest expected training costs, namely, the person at the beginning of the fictional labour queue. The supply of jobseekers and their educational attainment influences not only their probability of recruitment but also their earnings. Given a sufficient supply of educated workers, we expect employers to preferably hire graduates from the higher education system or the VET system even if the skill requirements for the job position are lower, leading to displacement of unskilled workers. In contrast, we anticipate that wages link to the job and not to the educational attainment of the jobholder. For the occupational level, Alda et al. (2020) demonstrate that a higher share of university graduates in an occupation has a negative effect on the returns to holders of a VET degree without an Abitur. If we apply that consideration to our examined educational groups, we can reason that employers sort VET graduates without an Abitur behind VET graduates with an Abitur in the labour queue. Consequently, we assume that a high share of higher education graduates in an occupation mainly affect holders of a VET degree without an Abitur, which brings us to our seventh hypothesis:

The gap between the occupation-specific wage returns of VET graduates with and without an Abitur narrows when we control for the share of higher education graduates in the occupation (H7)

Typically, the literature tends to generally distinguish between the occupation-specific knowledge acquired through VET and the general knowledge imparted by higher education. In contrast, we stick to an approach using a more refined definition of occupational specificity based on job-specific skills. The skill-weights approach (Lazear 2009) assumes a specific combination and weighting of skills for each occupation. The usability of an educational attainment and the skills acquired with it vary across occupations due to occupational specificity. Investigating Swiss employees' wages, Eggenberger et al. (2018) found that wages and occupational specificity are positively correlated, especially for employees staying in their training occupation. For Germany, Geel et al. (2011) show that firms' net training costs are connected to the specificity of an occupation. To amortise their vocational education and training investment, employers have a great interest that employees with specific skills stay in the establishment after apprenticeship, which reflects in the positive correlation between specificity and wages. Since VET holders with an Abitur face more career options like attending university after their apprenticeship, in specific occupations employers should thus prefer to invest in the vocational education and training of school leavers without an Abitur. They stay more likely in their training firm (cf. Brzinsky-Fay et al. 2016) inducing higher wage returns in specific occupations. Moreover, we know that the effect of signals depends on their context (cf. Piopiunik et al. 2020). International comparative literature of educational systems (e.g. Bol and van de Werfhorst 2011) and studies examining the impact of education over the life cycle (e.g. Forster and Bol 2018); demonstrate that high specificity fosters high signaling power of a degree. Transferring this assumption to VET degrees in Germany, we state that the higher the specificity of an occupation is, the higher is the signaling power of the respective degree. The higher signaling power of the VET degree outperforms the signaling effect of the Abitur. Consequently, in specific occupations VET graduates without 
an Abitur should experience an advantage in wage returns over general occupations and achieve similar wage returns as VET graduates with an Abitur. Taken together this argumentation leads to our final hypothesis:

The gap between the occupation-specific wage returns of VET graduates with and without an Abitur narrows when we control for occupational specificity (H8).

\section{Methods}

\section{Analytic approach}

We apply a hierarchical multi-level model because we analyse employees nested in occupations (e.g. Langer 2010; Rabe-Hesketh and Skrondal 2012). Accordingly, we distinguish two levels of analysis: individuals ${ }^{2}$ at the first level and occupations, ${ }^{3}$ as contexts, at the second level. We specify our models with an unstructured covariance matrix and cluster-robust standard errors for occupations.

As our first and second step, we empirically test $H 1$ to $H 2$ with a random-intercept/ random-slope model (RIRSM). Third, based on the results of the RIRSM, two inequality metrics are used to test $H 3$. Fourth, intercept-as-outcome models (I-as-OMs) serve as empirical measurements for hypotheses $H 4$ to $H 8$. Finally, in case that gaps in wage returns show up, we take a closer look on how the respective occupational characteristics shape educational wage returns for our study groups. We expand our analyses by specifying cross-level interactions referred to as random coefficient models (RCM) to examine whether the wage gaps between employees with a VET degree with and without an Abitur vary by the examined occupational characteristics.

The preceding model steps correspond to the general procedure of a multi-level analysis (see Langer 2010). The RIRSM is based on the following equations:

$$
\begin{aligned}
& \text { Level } 1: Y_{\mathrm{ij}}=\beta_{0 \mathrm{j}}+\beta_{1 \mathrm{j}} X_{\mathrm{ij}}+\delta_{10} W_{\mathrm{i} .}+r_{\mathrm{ij}} \\
& \text { Level 2: } \begin{aligned}
\beta_{0 \mathrm{j}} & =\gamma_{00}+u_{0 \mathrm{j}} \\
\beta_{1 \mathrm{j}} & =\gamma_{10}+u_{1 \mathrm{j}}
\end{aligned}
\end{aligned}
$$

Formula 1 delineates the variance of wages (i.e. $Y_{\mathrm{ij}}$ ) within occupations, with $\beta_{0 \mathrm{j}}$ being the intercept (varying only in context $\mathrm{j}$ ), $r_{\mathrm{ij}}$ the residual, $\delta_{10} W_{\mathrm{i}}$ the vector of the control variables at the first level (i.e. individual level) and $\beta_{1 \mathrm{j}} X_{\mathrm{ij}}$ the contextual slopes (i.e. occupation-specific wage returns to education) for the individual predictors $X_{\mathrm{ij}}$ nested in occupation $\mathrm{j}$. Since $\beta_{1 \mathrm{j}}$ varies for all occupations, we determine an inherent slope for each $\mathrm{j}$. Formula 2 includes the measurements of the context-specific intercept $\beta_{0 \mathrm{j}}$ and the context-specific slope $\beta_{1 \mathrm{j}}$. The context-specific intercept is calculated from $\gamma_{00}$, the constant of the regression (i.e. the average intercept for all $\mathrm{j}$ ), and $u_{0 \mathrm{j}}$, the random component of occupations. The context-specific slope is computed from the average slope $\gamma_{10}$ of $X$ for all contexts and its deviation from the average contextual slope (i.e. $\left.u_{1 j}\right)$.

\footnotetext{
${ }^{2}$ Individuals are indexed as $\mathrm{i}$ in the following.

${ }^{3}$ Occupations are indexed as $j$ in the following.
} 
To test the inequality of the contextual slopes (i.e. occupation-specific wage returns), we use two metrics: the Gini coefficient and the 90/10 decile ratio. A whole range of inequality measures exist (e.g. Coulter 2019), and we chose the respective metrics because they consider different parts of a distribution.

The Gini coefficient is a typical measurement of income dispersion. Its values range from zero to one, with a ratio of zero implying perfect equality and one maximum inequality. The index considers the entire distribution but reacts more strongly to changes in the middle range of the distribution, while it captures developments at the bottom and the top of the distribution rather poorly.

The $90 / 10$ decile ratio contrasts the top $10 \%$ value with the bottom $10 \%$ value. The larger the ratio, the greater the discrepancy between the top and bottom $10 \%$ of the distribution. A higher index indicates higher inequality. This index mainly responds to changes at the two extreme ends of the distribution and acts complementarily to the Gini coefficient.

In the next step of our analysis, we successively include occupational characteristics in separate models to investigate potential drivers of the wage return gap between VET graduates. Since tasks vary between and within occupations (e.g. Autor and Handel 2013), we control for the task share at the individual and the occupational level (cf. Rohrbach-Schmidt and Tiemann 2013). We implement I-as-OMs that extend formula 2 at the occupational level by the term $\gamma_{01} Z_{\text {.j: }}$

Level $2: \beta_{0 \mathrm{j}}=\gamma_{00}+\gamma_{01} Z_{\mathrm{j}}+u_{0 \mathrm{j}}$

$$
\beta_{1 j}=\gamma_{10}+u_{1 j}
$$

$\gamma_{01} Z_{\mathrm{j} j}$ measures the effect of the occupational characteristics $Z_{\mathrm{j}}$ at the second level on the variance of the intercepts across occupations $j$. The I-as-OMs enable us to assess which occupational characteristics contribute to the wage returns of VET graduates with and without an Abitur.

Last, we specify the additional RCMs for chosen occupational characteristics basing on the equation:

$$
\begin{aligned}
\text { Level } 2: \beta_{0 \mathrm{j}} & =\gamma_{00}+\gamma_{01} Z_{\mathrm{j}}+u_{0 \mathrm{j}} \\
\beta_{1 \mathrm{j}} & =\gamma_{10}+y_{11} * Z_{. j}+u_{1 \mathrm{j}}
\end{aligned}
$$

The interaction term expressed with $y_{11} * Z_{\text {.j }}$ specifies whether the context characteristic (i.e. the occupational characteristic) moderates the effect of the individual variable (i.e. the educational attainment) in the context $\mathrm{j}$ (occupation). The cross-level interactions in the RCMs encompass the interplay of the respective individual and contextual variables. Since both analytical levels and the variance in slopes affect the interaction term, the statistical power of cross-level interactions is rather complex. Detecting significant cross-level interactions is demanding due to the complexity of multi-level modelling (Mathieu et al. 2012).

We are aware that our multivariate empirical investigations may suffer from biases due to unobserved heterogeneity in individual attributes caused by student selection. Employees with a VET degree and an Abitur probably show higher innate ability and 
motivation. The unobservable characteristics of ability and motivation influence wage returns as well as educational attainments and bias our results.

To address this problem, we include school and training degree grades as a proxy for ability. However, it is important to recall the peculiarities of the German school system. The grades of secondary degrees and the Abitur are rather difficult to compare because they do not write similar exams and usually do not visit the same type of school. The degree of complexity behind the exams varies greatly. Simply put, pupils can only take the more complex Abitur exams if they have successfully passed secondary school, which means getting transferred from tenth to eleventh grade ${ }^{4}$ at a Gymnasium.

Further, we use a variable reflecting how strongly employees pursue career goals to account for motivation. One influencing factor for educational attainment and selection into our analytical groups is the family background (Müller et al. 2003). We use parental Erikson-Goldthorpe-Portocarero-Schema (EGP) to account for the anticipated differences between VET graduates with or without an Abitur. Additionally, we include indicators for socio-demographic characteristics such as age, gender and migration status to address individual differences.

Nonetheless, we cannot rule out all potential sources of unobserved heterogeneity, such as intelligence, adaptability or affinities. We likely overestimate our wage returns, although our chosen variable set limits the extent of this bias. Although we chose a highly suitable data source, we still face data limitations. As we draw on cross-sectional data, we cannot trace career developments and do not know whether VET graduates with an Abitur opt to go to university later on. Moreover, young people very likely select themselves into different occupations depending on their school-leaving certificates. Overall, our results do not allow us to draw causal conclusions.

To check the robustness of our analyses, we i) use the latest instead of the highest educational degree; ii) exclude employees younger than 36; iii) use the original instead of the imputed wage variable and iv) substituted tenure (and tenure square) by employees' potential experience. ${ }^{5}$ The estimated occupation-specific wage returns from our robustness checks hardly differ from the returns discussed in the paper.

\section{Data}

Our analytical approach requires data with detailed occupational codes and a sufficient number of cases. The BIBB/BAuA Employment Survey 2018 (Hall et al. 2020) meets these requirements; first, it comprises approximately 20,000 German core workers who are at least 15 years old and in paid employment for at least $10 \mathrm{~h}$ per week (RohrbachSchmidt and Hall 2020). Second, the data provide occupations at the 3-digit level of the 2010 German classification of occupations (i.e. Klasssifikation der Berufe [KldB] 2010) for each employee.

For our sample, we exclude workers who are self-employed, freelancers, independent contractors, civil servants or family workers as well as all employees under 18 or over 65 years. Further, we exclude all cases with missing values on the educational variable or

\footnotetext{
${ }^{4}$ In some federal states (e.g. Bavaria and Saxony), pupils visiting a Gymnasium automatically achieve a secondary school-leaving certificate by passing the tenth grade without writing an additional exam.

${ }^{5}$ We operationalised the potential experience using a common calculation method. We subtracted the years of education (school and vocational training) and the number six from the employees' age.
} 
on the task and tenure variables. Last, we disregard observations with no valid occupational information or with military occupations. Overall, these restrictions leave us with a sample of 15,640 cases.

\section{Variables}

Our main independent variable is educational attainment. Instead of the latest degree, we consider the highest degree as the one affecting the wage and refer to it in our analyses.

We distinguish five levels of educational attainment:

1. No degree ( $9 \%$ of the employees in the sample ${ }^{6}$ );

2. VET degree without an Abitur (VET1 $\left.{ }^{7}\right)$ (50\% of the employees in the sample);

3. VET degree with an Abitur (VET2) (10\% of the employees in the sample);

4. Advanced VET degree such as a master or technician degree ( $8 \%$ of the employees in the sample) and

5. Higher education (HE) degree (i.e. (applied) university degree) (23\% of the employees in the sample).

The focus of our analyses is on the second and third level of educational attainments, namely, VET1 and VET2. In the following, we estimate occupation-specific wage returns to education for both. The remaining categories serve as controls relative to the reference category (i.e. no degree).

The current occupations according to the three digit KldB 2010 codes act as contexts in our models. To obtain sufficiently large variation within each occupation, we only consider occupations including at least 20 observations and a minimum of 3 observations per occupation in the unskilled, VET1 and VET2 categories. We assign occupations with a smaller number of cases to similar occupations ${ }^{8}$ (see Additional file 1: Table S1). After mapping, we end up with 78 occupations as contexts for our analyses. We choose five of these occupations to examine occupation-specific wage returns in more detail. We select occupations from different sectors with a nearly balanced gender ratio and sufficient representation of our selected levels of educational attainment. The respective occupations are cooks, drivers of vehicles in road traffic, sales professionals, education and social workers and advertising and marketing professionals.

The operationalisation of our five occupational characteristics is as follows (cf. Table S2 in Additional file 1 for a detailed description): We categorize licensed occupations according to Haupt (2016b). We operationalise the individual task shares in line with the relevant theory and research practice (cf. Rohrbach-Schmidt and Tiemann 2013). We then aggregate the individual shares to the occupational level. The shares of women and higher education degrees comprise individual shares aggregated to the occupational level. We calculate occupational specificity as the difference between the sample and occupational mean of required specialist knowledge (cf. Geel et al. 2011). We consider

\footnotetext{
${ }^{6}$ All values are weighted. The source is the BIBB/BAuA Employment Survey 2018.

7 In the following, we abbreviate the designations to VET1 and VET2 as well as HE for easier reading.

${ }^{8}$ In cases in which a mapping was not reasonable, the respective occupations $(n=12)$ still serve as context variables even though we calculate no occupation-specific returns.
} 
occupations to be specific if they require unique skill combinations; put differently, the higher the index is, the more specific the occupation.

The monthly gross wage serves as the dependent variable in our analyses. To compensate for missing values, we use the imputed wage variable provided by the BIBB-FDZ.

We control in our analyses for the following individual-level variables: gender, region, age, tenure, migration status, family status and children living in the household. Additionally, we control for the following employment characteristics: working hours, sector, firm size and works councils. Additional file 1: Table S2 reports the data preparation for all control variables.

\section{Results and discussion}

\section{Comparing VET graduates with and without an Abitur}

Before considering wage differentials, we outline our descriptive results to reveal inherent differences between our study groups and across occupations. Table 1 contains the statistics for the full sample and differentiated for employees with a VET degree with an Abitur and those without an Abitur. The share of women among VET2 graduates markedly exceeds the share among VET1 graduates. Our descriptive results further reveal that VET2 graduates are more likely to live in West Germany (78\% of VET1 graduates vs. $83 \%$ of VET2 graduates) and be foreign-born (6\% vs. $12 \%)$; they are less often married (55\% vs 51\%); and they more often have children under 18 (32\% vs. 37\%). Moreover, employees with a VET2 are slightly younger ( 45 vs. 41 years) and have a shorter tenure (13 vs. 11 months) while they work on average the same number of hours per week (37 h) (Table 1).

Another important differentiating characteristic between both educational groups is socio-demographic background, measured via parental EGP. Müller et al. (2003) state, 'Germany appears to be the nation in which class differentials in educational outcomes are the most pronounced' (p. 23f.). This claim holds for our sample, with 35\% of parents of VET2 graduates belonging to the managerial and professional worker class (high and low). In contrast, the parents of VET1 graduates mostly belong to the class of skilled (25\%) and semi-skilled/unskilled manual workers (22\%).

As stated before, we cannot directly compare the school-leaving grades of VET1 and VET2 graduates. However, more VET2 graduates obtained a very good grade (5\% vs. 7\%). Comparing the VET degree grades makes the difference clearer: $24 \%$ of the VET2 graduates obtained a very good grade, but only $10 \%$ of VET1 graduates did so.

The career aspiration item demonstrates that employees holding a VET2 degree pursue their career more strongly. However, the share of employees not strongly pursuing their career does not show notable differences between both groups.

Differences concerning employment characteristics between the two groups manifest mainly in the fact that more employees with a VET1 degree work in the metal electrical industry (19\% vs. 12\%), whereas more of the employees with a VET2 degree work in health and social services (15\% vs. 23\%). Further, more VET1 graduates work in small firms, while more VET2 graduates work in large firms. The share of work councils is similar for both.

As expected from our theoretical outline, employees with a VET1 degree perform analytic and interactive tasks less frequently (50\% vs. $64 \%)$ and routine tasks more often 
Table 1 Key variables of the data set

\begin{tabular}{|c|c|c|c|}
\hline Categorical variables & Full Sample (\%) & VET1 (\%) & VET2 (\%) \\
\hline \multicolumn{4}{|l|}{ Educational attainment } \\
\hline No degree & 9.24 & & \\
\hline VET1 degree & 50.28 & & \\
\hline VET2 degree & 9.70 & & \\
\hline Advanced VET degree & 7.56 & & \\
\hline HE degree & 23.22 & & \\
\hline Gender (Male) & 53.38 & 53.94 & 42.10 \\
\hline Region (West) & 80.05 & 78.08 & 83.84 \\
\hline \multicolumn{4}{|l|}{ Erikson-Goldthorpe-Portocarero-Schema (EGP) } \\
\hline I Higher managerial and professional workers & 14.50 & 8.00 & 18.04 \\
\hline II Lower managerial and professional workers & 13.25 & 8.85 & 17.65 \\
\hline Illa/b Routine clerical and service and sales work & 8.11 & 8.40 & 10.43 \\
\hline IVa Small self-employed with employees & 3.66 & 3.18 & 3.73 \\
\hline IVb Small self-employed without employees & 1.82 & 1.86 & 1.98 \\
\hline V Manual supervisors & 3.41 & 3.25 & 2.10 \\
\hline VI Skilled manual workers & 20.67 & 25.29 & 17.53 \\
\hline Vlla Semi- and unskilled manual workers & 17.42 & 21.70 & 12.70 \\
\hline VIllb Agricultural labour & 2.36 & 3.21 & 1.72 \\
\hline IVc Self-employed farmers & 3.10 & 3.68 & 3.58 \\
\hline \multicolumn{4}{|l|}{ Migration status } \\
\hline No & 80.21 & 85.98 & 78.94 \\
\hline Yes & 8.38 & 8.06 & 9.07 \\
\hline Foreigner & 11.30 & 5.87 & 11.73 \\
\hline Married (yes) & 54.02 & 55.21 & 51.02 \\
\hline Children under 18 (yes) & 33.28 & 31.73 & 36.81 \\
\hline \multicolumn{4}{|l|}{ School-leaving grade } \\
\hline Very good & 9.61 & 5.02 & 7.20 \\
\hline Good & 48.60 & 45.82 & 50.56 \\
\hline Satisfying & 32.09 & 37.58 & 37.57 \\
\hline Sufficient & 2.68 & 3.29 & 2.13 \\
\hline \multicolumn{4}{|l|}{ Grade training degree } \\
\hline Very good & 15.53 & 9.72 & 23.95 \\
\hline Good & 46.84 & 51.03 & 53.68 \\
\hline Satisfying & 22.01 & 31.40 & 16.09 \\
\hline Sufficient & 2.38 & 3.76 & 2.19 \\
\hline \multicolumn{4}{|l|}{ Pursuit the goal of a career } \\
\hline Very strong & 7.27 & 5.28 & 8.14 \\
\hline Strong & 28.66 & 24.20 & 29.66 \\
\hline No much & 40.34 & 42.50 & 42.58 \\
\hline Not at all & 21.75 & 25.94 & 18.49 \\
\hline Part/Part & 0.87 & 1.09 & 0.65 \\
\hline \multicolumn{4}{|l|}{ Firm size } \\
\hline Under 9 & 12.47 & 14.41 & 12.92 \\
\hline 9 to 49 & 26.51 & 27.62 & 26.94 \\
\hline 50 to 250 & 24.78 & 24.87 & 24.02 \\
\hline Over 250 & 32.66 & 29.29 & 33.41 \\
\hline \multicolumn{4}{|l|}{ Sector } \\
\hline Agricultural/Mining & 2.31 & 2.48 & 1.78 \\
\hline Manufacturing & 11.04 & 12.46 & 8.02 \\
\hline
\end{tabular}


Table 1 (continued)

\begin{tabular}{llll}
\hline Categorical variables & Full Sample (\%) & VET1 (\%) & VET2 (\%) \\
\hline Metal and electrical industry & 17.35 & 19.06 & 11.99 \\
Construction industry & 6.02 & 8.54 & 3.43 \\
Trade & 9.61 & 11.62 & 9.18 \\
Private services & 15.04 & 14.53 & 13.93 \\
Banks/insurance companies & 2.92 & 1.78 & 6.14 \\
Business-related services & 7.76 & 5.80 & 8.03 \\
Public service & 12.44 & 8.34 & 14.44 \\
Health and social services & 15.20 & 15.02 & 22.94 \\
Works council (yes) & 56.49 & 53.14 & 54.98 \\
\hline Metric variables & Mean (standard deviation) & & \\
Tenure & $11.29(10.73)$ & $12.63(11.15)$ & $10.50(9.80)$ \\
Working hours & $37.79(10.94)$ & $37.52(10.62)$ & $37.00(10.22)$ \\
Age & $43.24(11.73)$ & $44.79(11.44)$ & $40.55(11.28)$ \\
Share of analytic and interactive tasks & $0.58(0.24)$ & $0.50(0.23)$ & $0.64(0.20)$ \\
Share of routine tasks & $0.23(0.17)$ & $0.27(0.17)$ & $0.19(0.13)$ \\
$N$ & 15,640 & 6349 & 2084
\end{tabular}

Source: BIBB/BAuA Employment Survey 2018, all values are weighted

Population: German employees

Percentages missing up to $100 \%$ are due to missing values

( $27 \%$ vs. $19 \%$ ). The share of analytic and interactive tasks lies below the sample average of $58 \%$ for VET1 graduates and above the sample average for VET2 graduates. We find the opposite for routine tasks: A share above the sample average (23\%) for VET1 and below the sample average for VET2 degree holders. Overall, the descriptive results exemplify the disparities between our study groups of VET degree holders with different school-leaving certificates.

We turn our attention now to wages, our dependent variable, to see if differentials between our study groups emerge at the descriptive level. Unadjusted, employees with a VET1 degree earn on average approximately 2,500€ per month in gross wages and those with a VET2 degree 2,800€. This distinct gap of approximately $300 €$ between the mean wages of the two groups points towards systematic differences.

Figure 2 depicts the mean and standard deviation of the wages in our five selected occupations and the sample mean wage (approximately 2,900€). At first sight, comparing the mean wages reveals apparent differences. Sales professionals with a VET1 earn, for example, nearly $700 €$ less than VET1 graduates on average. In contrast, employees with a VET2 degree working as advertising and marketing professionals earn approximately $400 €$ more than VET2 graduates and $300 €$ more on average than all the employees in the sample. Contrasting the mean wages of our study groups reveals that employees with an Abitur earn higher wages. This difference holds for all five example occupations, although the amount of the wage surplus varies. For example, cooks achieve comparably high mean wages irrespective of their school-leaving certificate. In contrast, the difference between VET1 and VET2 advertising and marketing professionals reaches $750 €$. The standard deviation also varies considerably across occupations; education and social workers who obtained a VET1 degree have a standard deviation of approximately $900 €$, whereas the deviation of drivers of vehicles 


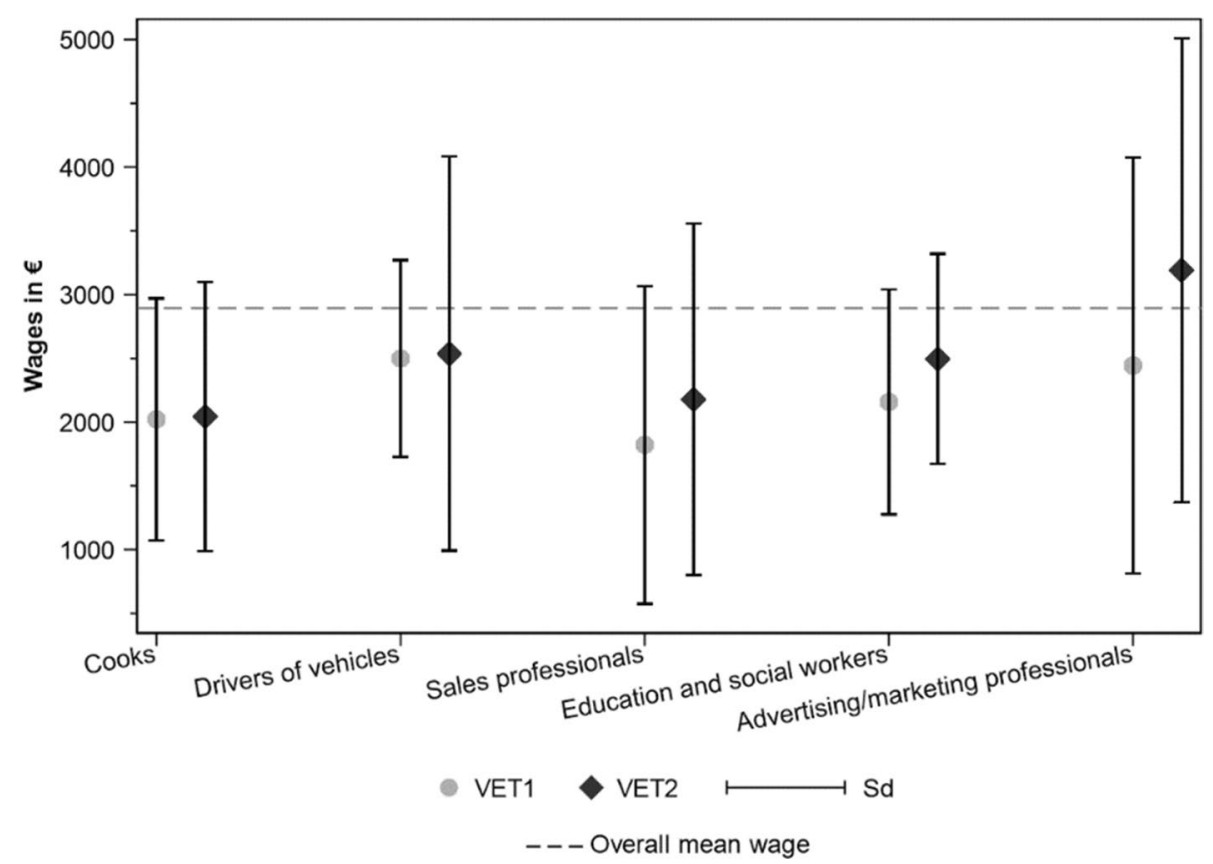

Fig. 2 Means and standard deviations of wages in selected occupations (Source: BIBB/BAuA Employment Survey 2018, weighted values. Population: German employees)

in road traffic with a VET2 degree reaches $2300 €$. The descriptive findings reveal wage differentials between VET graduates according to their school-leaving certificate and current occupation. Considering the descriptive results call for moving our analyses forward to the multivariate results.

\section{Occupational characteristics}

Before we turn to our multivariate analyses, we descriptively look at our occupational characteristics in our five selected occupations. The 3-digit occupations are either licensed (education and social workers) or not (e.g. sales professionals), and nearly no occupation lies in between. Table 2 displays the shares of each of the five selected occupational characteristics for all and our example occupations.

For the considered task shares, we find noticeable variation across the occupations. Overall, the share of analytic and interactive tasks accounts for $61 \%$ of all tasks in the sample, $33 \%$ of the tasks of drivers of vehicles in road traffic and $85 \%$ of the tasks of advertising and marketing professionals. The opposite picture emerges for routine tasks (22\%); drivers of vehicles in road traffic perform these tasks at above-average levels (38\%) and advertising and marketing professionals at below-average levels (10\%).

As is known from the literature, we find in our sample a clear separation of women (education and social workers), men (drivers of vehicles in road traffic) and mixed (cooks) occupations. Accordingly, considerable variation between occupations appears.

The share of employees with higher education degrees ranges in our example occupations from 5\% (cooks) to 51\% (advertising and marketing professionals). The sample average amounts $30 \%$. 
Table 2 Characteristics of selected example occupations and for all analysed 78 occupations

\begin{tabular}{|c|c|}
\hline \multicolumn{2}{|l|}{ Share of licensed occupations } \\
\hline Overall & $0.12(0.32)$ \\
\hline Cooks & 0 \\
\hline Drivers of vehicles in road traffic & 0 \\
\hline Sales professionals & 0 \\
\hline Education and social workers & 1 \\
\hline Advertising and marketing professionals & 0 \\
\hline \multicolumn{2}{|l|}{ Share of analytic and interactive tasks } \\
\hline Overall & $0.61(0.17)$ \\
\hline Cooks & 0.36 \\
\hline Drivers of vehicles in road traffic & 0.33 \\
\hline Sales professionals & 0.63 \\
\hline Education and social workers & 0.62 \\
\hline Advertising and marketing professionals & 0.85 \\
\hline \multicolumn{2}{|l|}{ Share of routine tasks } \\
\hline Overall & $0.22(0.10)$ \\
\hline Cooks & 0.33 \\
\hline Drivers of vehicles in road traffic & 0.38 \\
\hline Sales professionals & 0.20 \\
\hline Education and social workers & 0.09 \\
\hline Advertising and marketing professionals & 0.10 \\
\hline \multicolumn{2}{|l|}{ Share of women } \\
\hline Overall & $0.46(0.29)$ \\
\hline Cooks & 0.55 \\
\hline Drivers of vehicles in road traffic & 0.10 \\
\hline Sales occupations & 0.68 \\
\hline Education and social workers & 0.80 \\
\hline Advertising and marketing professionals & 0.55 \\
\hline \multicolumn{2}{|l|}{ Share of university degree } \\
\hline Overall & $0.30(0.24)$ \\
\hline Cooks & 0.05 \\
\hline Drivers of vehicles in road traffic & 0.05 \\
\hline Sales occupations & 0.11 \\
\hline Education and social workers & 0.39 \\
\hline Advertising and marketing professionals & 0.51 \\
\hline \multicolumn{2}{|l|}{ Occupational specificity in \% } \\
\hline Overall & $0.16(0.95)$ \\
\hline Cooks & 1.30 \\
\hline Drivers of vehicles in road traffic & 1.76 \\
\hline Sales professionals & 1.06 \\
\hline Education and social workers & 0.72 \\
\hline Advertising and marketing professionals & -0.83 \\
\hline
\end{tabular}

Source: BIBB/BAuA Employment Survey 2018

Values in brackets show standard deviations for all analysed 78 occupations

The occupational specificity measure ranges between the values of -1.8 and 2.3 for all occupations in the sample, with low values implying more general and high values more specific occupations. Looking at our example occupations allows us to categorise advertising and marketing professionals - with a value only slightly above the average $(0.21$ 


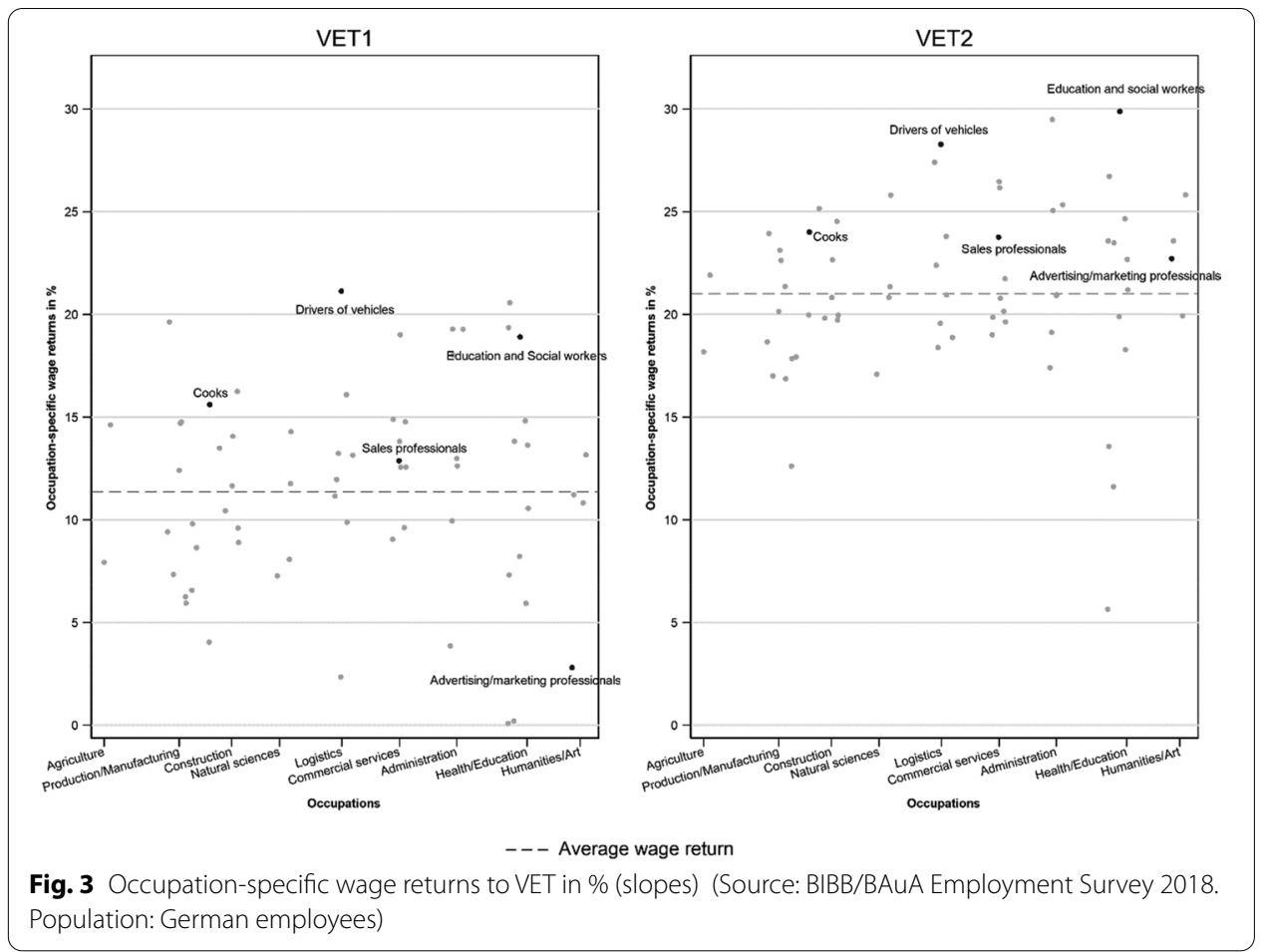

compared to the sample average of 0.16) - as general and the other four occupations with a value above the average - as rather specific occupations. Taken together, the presented characteristics illustrate great variation across our example occupations, making it rewarding to deepen our analysis.

\section{Comparing average wage returns for VET graduates}

Expanding our descriptive results, we calculate average and occupation-specific wage returns for VET1 and VET2 graduates. ${ }^{9}$ Figure $3^{10}$ depicts the wage premiums of VET1 and VET2 degrees relative to the average wages of unskilled employees for each of our 78 analysed occupations (see Additional file 1: Table S5 for all occupation-specific slopes). The dashed line represents the average wage return to a VET1 or a VET2 degree across all occupations.

First, we explore basic differences between the average wage returns to education for VET1 and VET2 irrespective of occupational affiliation. Employees with a VET1 degree achieve $11.4 \%$ and employees with a VET2 degree $21 \%$ higher wages than unskilled workers. Both coefficients for VET degrees are highly significant at the $1 \%$ level. For employees with an Abitur, the wage return is nearly double that of employees without an Abitur. Considering the average remuneration for a VET degree in our sample, the two to three extra years of schooling prove worthwhile. These findings confirm H1a and contradict $H 1 b$, supporting HCT and years of schooling instead of the VET degree serving

\footnotetext{
${ }^{9}$ Table S3 in Additional file 1 presents all cell sizes and the wage variation per occupation separately by level of educational attainment.

${ }^{10}$ In the following, we present only partial results, cf. Table S4 in Additional file 1 for the full regression results.
} 
as a signal of productivity. Even though the credential serves as a wage effective attribute in Germany, our results suggest that the VET degree does not abrogate the influence of the school-leaving certificate.

\section{Occupation-specific gap between wage returns for VET graduates}

Second, we investigate the wage returns in particular occupations and whether VET graduates experience wage premiums or wage losses depending on their previous schooling. Initially, we observe that the occupation-specific returns vary considerably around the average wage return for both VET degrees (cf. Fig. 3). The occupationspecific wage returns range from a maximum of $30 \%$ for education and social workers (VET2) and a minimum of $0.08 \%$ for medical and health care professionals (VET1). Generally, VET1 graduates' occupation-specific wage returns vary more widely around the average return than the returns of VET2 graduates. Considering our five example occupations reveals occupational differences. In terms of occupation-specific wage returns for VET1 degrees, drivers of vehicles in road traffic with this degree earn $21 \%$ and advertising and marketing professionals only approximately $3 \%$ more than unskilled employees. For VET2 degrees, we also find remarkable occupational differences. For education and social workers who hold this degree, the wage premium rises up to $30 \%$, whereas medical health and care workers earn only $5 \%$ more than unskilled employees.

In view of this variation in wage returns across occupations, the question arises whether the wage differences among VET degree holders depend on the school-leaving certificate. Figure 3 clearly affirms the Abitur's impact on occupation-specific wage returns. VET2 graduates earn higher wage returns in all 78 occupations. Hence, we can confirm $H 2$ that employees with a VET2 degree achieve pervasive higher occupationspecific wage returns.

To illustrate that $H 2$ also holds if we contrast occupations in more detail, Fig. 4 depicts the ten occupations with the highest and lowest differences in occupation-specific wage returns. For easy presentation, we present the wage returns in euros. In direct comparison, we note that the wage returns of employees with VET2 degrees are always above those with VET1 degrees. Even in occupations with smaller differences between both levels of educational attainment (e.g. medical receptionists and assistants), VET2 graduates gain a wage boost of approximately $85 €$. Considering occupations with the largest differences (e.g. advertising and marketing professionals, drivers and operators of vehicles), the wage gap between VET graduates reaches up to $401 €$. Especially for drivers and operators of vehicles, a large wage gap opens up. Employees with a VET1 degree earn only slightly more (47€) than unskilled employees, whereas VET2 graduates earn considerably more (347€). The findings emphasise employees' considerably varying wage returns due to their school-leaving certificate even if they work in the same occupation and hold the same VET degree.

\section{Revealing inequalities in occupation-specific wage returns for VET graduates}

As already seen in Figs. 3 and 4, occupation-specific wage returns vary differently for both VET degrees. Therefore, we third seek to measure these visible differences statistically. We apply two inequality metrics to test whether VET1 graduates experience higher 


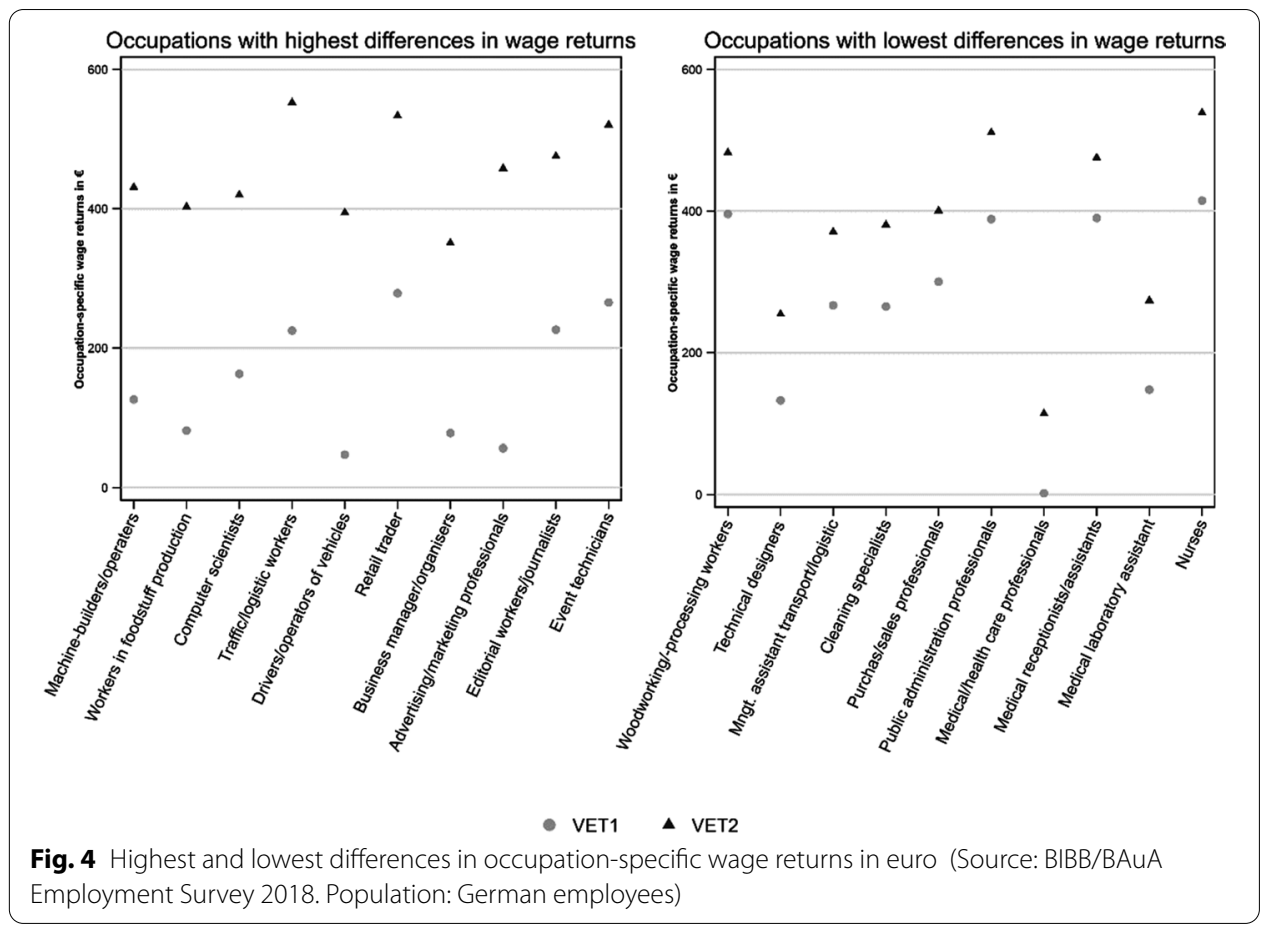

Table 3 Inequality measures of occupation-specific wage returns

\begin{tabular}{lll}
\hline Inequality measure & VET1 & VET2 \\
\hline Gini coefficient & 0.25 & 0.12 \\
p90/p10 ratio & 3.25 & 1.72 \\
\hline
\end{tabular}

Source: BIBB/BAuA Employment Survey 2018

Population: German employees

inequality in wage returns across occupations than VET2 graduates. We use the distribution of occupation-specific wage returns (i.e. the slopes) for measurement. Concretely, we calculate the Gini coefficient and the ratio of the 90th and 10th deciles.

In direct comparison, the metrics point in the same direction (see Table 3): For both inequality measures, the values for VET1 graduates clearly lie above those for VET2 graduates.

The Gini coefficient for VET2 graduates equals almost zero, meaning that their wage returns are approximately equal. Comparatively, the VET1 graduates' Gini coefficient doubles. Nevertheless, the still-low value suggests that the wage returns of VET1 holders resemble each other.

We examine the 90/10 decile ratio to evaluate the differences at the upper and lower ends of the distribution because the Gini coefficient reacts sensitive to differences in the middle range of the distribution. The metrics reveal that VET1 graduates at the top of the distribution (i.e. the 90th percentile) achieve occupation-specific wage returns that are approximately three times higher than those of employees at the bottom of the distribution (i.e. the 10th percentile). For VET2 graduates, the differences diminish; the returns of employees at the top of the distribution are not even twice as high as those of employees at the bottom of the distribution. 


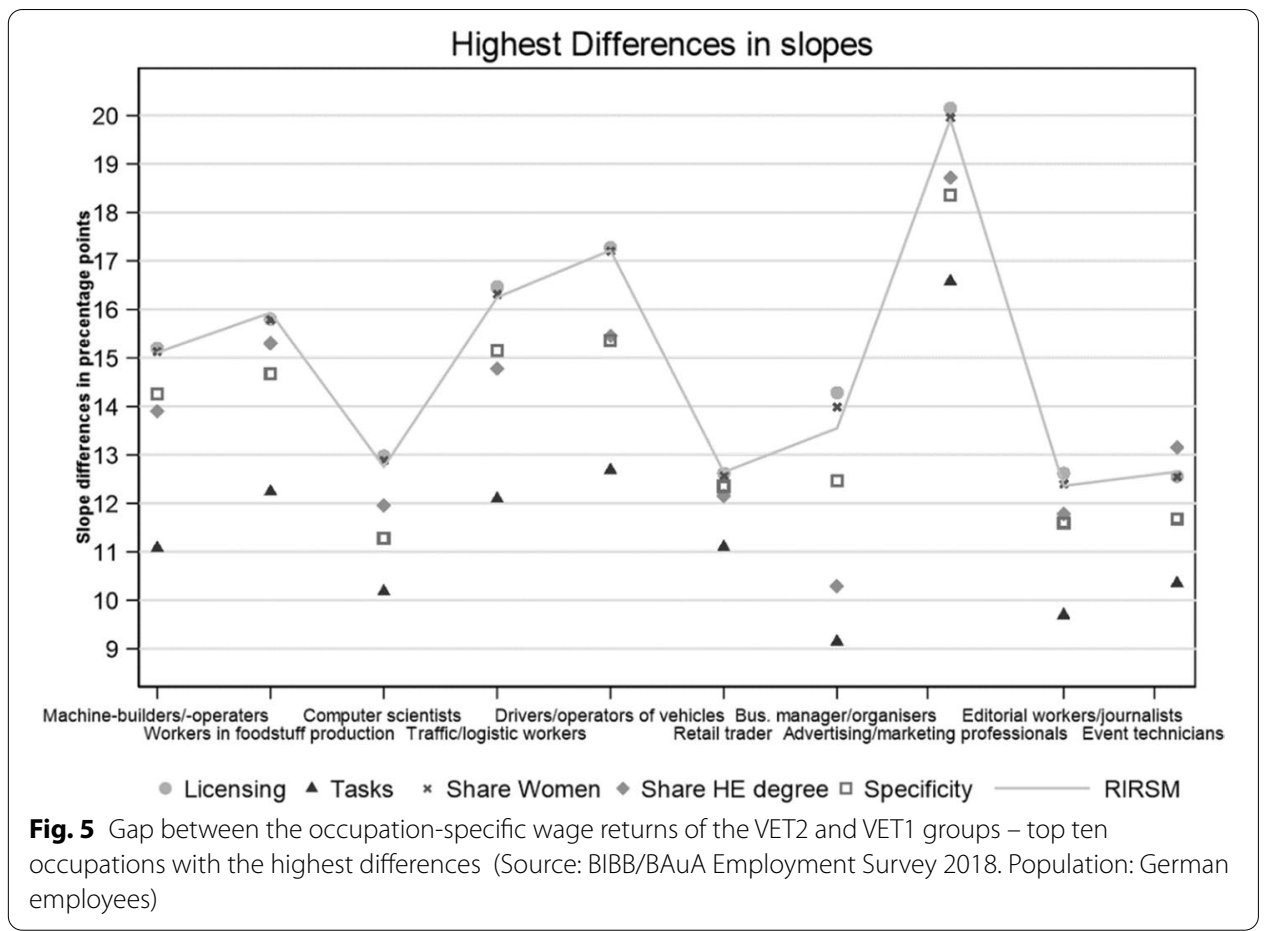

In line with $H 3$, the applied inequality metrics substantiate that graduates without an Abitur experience higher inequality in their occupation-specific wage returns. The results suggest that two to three additional years of schooling contribute to inequality reduction instead of widening the dispersion of wage returns. Additionally, the results convey that inequalities are concentrated at the upper and lower boundaries because the Gini coefficient implies lower inequality than does the 90/10 ratio.

\section{Occupational characteristics shaping wage return gaps between VET graduates}

Fourth, we assess the extent to which our five selected occupational characteristics influence the gap in occupation-specific wage returns between VET graduates with and without an Abitur.

We calculate the difference in wage returns between VET1 and VET2 graduates within the same occupation. The model without occupational characteristics (RIRSM) serves as a reference to determine changes in the wage gaps obtained by the models controlling for occupational characteristics. For clear and comparable presentation of our results, we display two graphs for the ten occupations with the highest and lowest differences in wage returns according to the RIRSM (cf. Fig. 4).

With H4, we hypothesised that the wage gap between VET1 and VET2 graduates increases if we control for licencing. Referring to Fig. 5 on the occupations with the highest wage differentials, we find that licencing does not lead to a reduction in the wage returns gap for VET1 and VET2 graduates because the licencing values equal those of the reference model, plotted as a grey line in the graph. Considering that most of the occupations are not licensed, this result is not surprising. Figure 6 reveals that for occupations with a high share of licencing (i.e. medical and health care professionals, medical laboratory assistant and nurses), controlling for licencing diminishes the wage return 


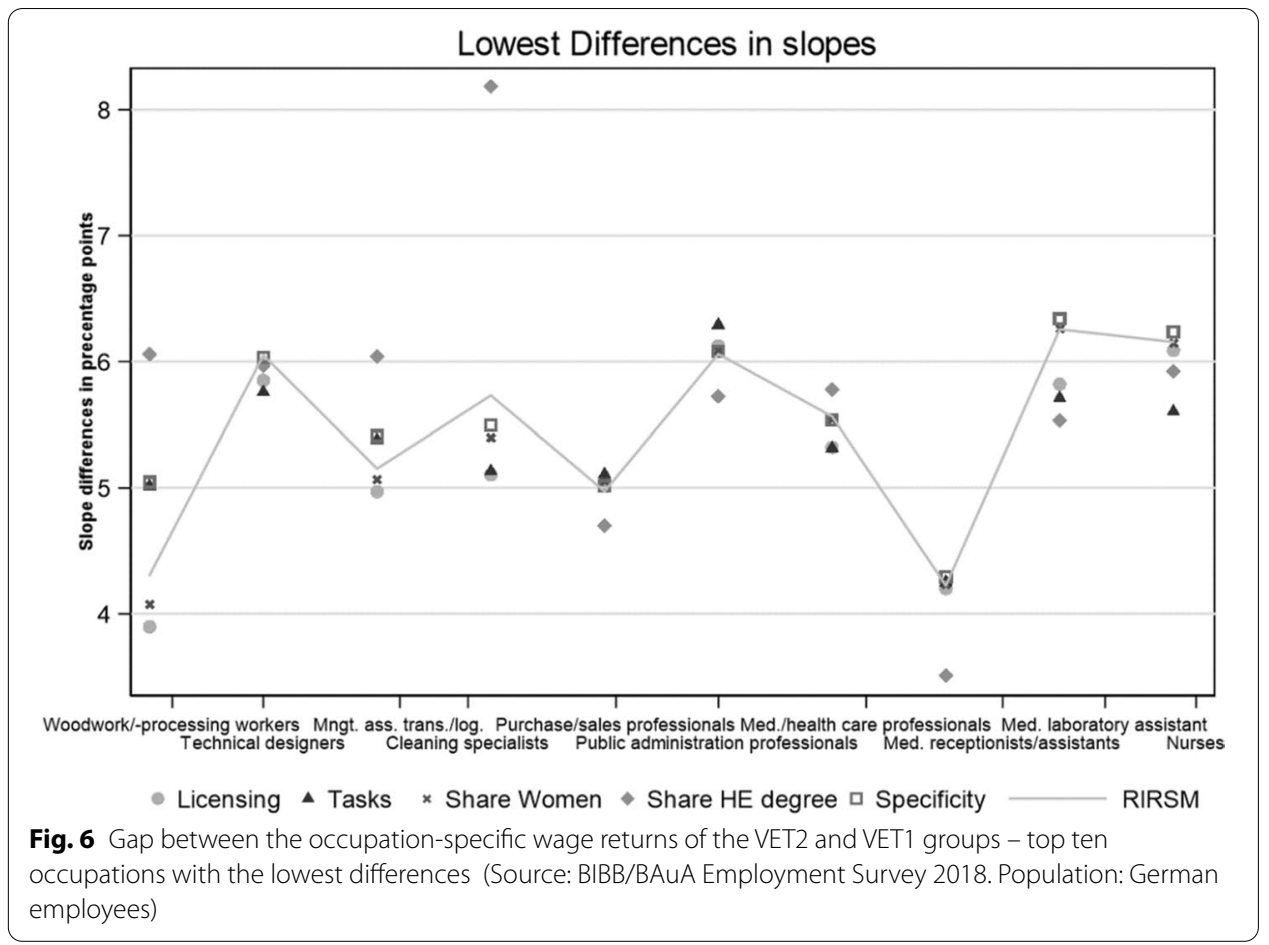

gap between VET graduates with and without an Abitur but only by 0.1 to 0.4 percentage points. Taken together, controlling for licencing results in a negligible reduction of the wage return gap between VET graduates. Hence, we reject $H 4$.

What do the results say when we control for the shares of analytical, interactive and routine tasks performed? Figs. 5 and 6 reveal that except for woodworking and -processing workers, management assistants in transport and logistic, purchase and sales professionals and public administration professionals, controlling for the share of tasks narrows the gap in wage returns between our study groups. For example, for traffic and logistic workers, the gap shrinks from 16 to 12 percentage points and for advertising and marketing professionals from 20 to 16.6 percentage points. We affirm $H 5$, which assumes that the gap in wage returns between VET1 and VET2 should shrink if we control for tasks, even though we find exceptions.

For a more detailed investigation of whether the share of performed tasks in an occupation shapes the detected occupation-specific gape in wage returns, we model crosslevel interaction terms (cf. Additional file 1: Table S4, RCM Models 7-10). We analyse if shares of analytic/interactive tasks and routine tasks in occupations are differently rewarded based on the employees' educational level. The cross-level interaction reveals differences between our study groups but the coefficients are not significant. Compared to VET2 graduates, VET1 graduates achieve lower returns for analytic/interactive tasks if they work in an occupation with a high share of analytic/interactive tasks. In turn, VET 1 generate higher returns for routine tasks if they work in an occupation with a high share of routine tasks.

Extending our model by the share of women, the gap between the occupation-specific wage returns of employees with a VET degree either with or without an Abitur remains 
almost stable - contradicting our sixth hypothesis. The rejection of $H 6$ suggests that the share of women in occupations does not contribute to the occupation-specific wage return gap between VET1 and VET2 graduates.

The share of HE degrees moves the occupation-specific wage returns in different directions for employees with a VET1 or VET2 degree, yielding smaller gaps. For example, the gap between the VET1 and VET2 groups among drivers and operators of vehicles shrinks from approximately 17 percentage points in the RIRSM to approximately 15.5 percentage points in the I-as-OM controlling for the HE degree share (cf. Fig. 5). Consequently, we confirm $H 7$. Nevertheless, we again find exceptions, e.g. cleaning specialists, where the difference between the occupation-specific wage returns of VET1 and VET2 graduates rises remarkably from 5.7 to 8.1 percentage points (cf. Fig. 6). The reason for the striking increase remains unclear. Even though the share of HE degrees is very low, the same holds for medical receptionists and assistants for whom we find a shrinking gap in the occupation-specific wage returns.

We test if the share of HE degrees moderates the effect of the educational attainment within an occupation but find no significant cross-level interaction. Nevertheless, the coefficients suggest that the share of university graduates has a different effect for VET1 and VET2 graduates - employees with a VET2 degree benefit more from high shares of university graduates working in the same occupation.

The gap between occupation-specific wage returns of VET graduates with and without an Abitur narrows when we control for occupational specificity (H8); hence, we confirm our eighth hypothesis. Computer scientists typify the reduction, and the respective wage gap shrinks from 13 to 11 percentage points (cf. Fig. 5). Nonetheless, not all occupations mirror the finding of reduction. In particular, occupations with already small gaps in the RIRSM deviate. For example, woodworking and -processing workers show a greater gap and medical receptionists and assistants a similar gap when we control for occupational specificity (cf. Fig. 6). Estimating the cross-level interaction proposes no moderating effect of occupational specificity. Moreover, the cross-level interaction indicates that the remuneration of VET graduates varies not by the school-leaving certificate or the occupation.

Taken together, our multivariate results provide a detailed picture of wage gaps between employees with the same VET degree but different school-leaving certificates. Our analyses illustrate how occupational characteristics shape differences in the wage returns of employees with or without an Abitur. The results suggest that previous schooling not only generally drives the level of employees' wage returns to education in Germany but also within and across occupations. In our sample, VET graduates with an Abitur experience a wage premium across all analysed occupations. A deeper analysis of occupational characteristics unveils three occupational characteristics moulding the wage gaps between VET1 and VET2 graduates. Three of the five selected occupational characteristics narrow differences in the occupation-specific wage returns between VET1 and VET2 graduates, albeit with a few exceptions. Our results suggest that tasks, the share of HE degrees and occupational specificity contribute to the finding that employees with a VET2 degree earn higher wage returns. From our selected characteristics, the task share turns out to be the main driver of the differentials in occupationspecific wage returns between our study groups. 
The mechanisms behind the effect of our occupational characteristics remain unclear, yet. However, the cross-level interactions suggest that VET2 graduates are better paid for analytic/interactive tasks and benefit more from a high share of HE degrees.

Wrapping up, we still observe occupation-specific wage gaps between both levels of educational attainments, buttressing the assumption that previous schooling affects the wages of employees with a VET degree. As we initially assumed, combining a VET degree with an Abitur cannot only reduce wage inequality but also leads to higher wage returns across all occupations.

\section{Conclusions}

By exploiting the latest wave of the BIBB/BAuA Employment Survey 2018, this study compared the wage returns of VET graduates according to their school-leaving certificate. The theoretical approaches discussed in this paper provide mixed explanations for whether and why VET graduates - who have obtained the same qualification - generate different wage returns. We posited that the occupation-specific wage returns vary across employees with a VET degree according to whether they do or do not hold an Abitur as well as according to occupational characteristics.

Our descriptive results reveal that VET graduates with and without an Abitur are differentiated in terms of their sociodemographic attributes, performed tasks, career ambitions and parental social background. The findings point to the need to deepen our analyses of differences between VET graduates with and without an Abitur.

First, for employees with a VET degree and an Abitur, we found wage returns that are almost twice as high as those of employees with a VET degree and no Abitur. Second, we calculated occupation-specific wage returns for both of our study groups. VET graduates with an Abitur earn higher wage returns in all 78 analysed occupations. Third, applying two inequality measures revealed that VET graduates without an Abitur experience higher wage inequality. Fourth, the estimated disparities in wage returns point to underlying differences between our two VET study groups, which encouraged us to examine the occupational characteristics of five selected occupations. Extending our multi-level analysis stepwise by occupational characteristics revealed that the task composition, the share of higher education degrees in an occupation, and occupational specificity can reduce the gap in wage returns between employees with VET degrees either with or without an Abitur.

Research can benefit from the insights that our findings give concerning occupationspecific wage returns. Our study suggests that differentiating between VET graduates with and without an Abitur is reasonable since empirical differences between both study groups appear even after we control for occupational characteristics that affect wages. We contribute to the literature by pointing to number of years of schooling as a relevant signal influencing wages in Germany. In our sample, the VET credential does not abrogate the influence of previous schooling. From a human capital perspective, one could argue that investing in two to three years of schooling could be a monetarily rewarding strategy for those interested in taking up an apprenticeship. Further, we enrich the discussion on wage inequalities by demonstrating that VET graduates without an Abitur experience higher wage inequality - a result suggesting that their current occupation is more decisive for them than for VET graduates with an Abitur. Last, the task composition of occupations affects wage returns differently for our study groups and accounts 
for disparities between them. Our findings buttress the impact of task composition on wages already described in the literature.

Our analyses face some limitations. Considering occupational characteristics provides fruitful insights on the relevance of occupations for the differences in wage returns among VET graduates. Nevertheless, our study lacks an identification of the underlying mechanisms. We cannot provide evidence on why some occupations are exceptions in terms of reducing or increasing gaps in wage returns or whether occupational characteristics effects vary in strength for our two study groups. The cross-level interactions indicate that two of our selected occupational characteristics induce differences in wage returns between VET graduates with or without an Abitur. First, the interactions suggest that employees get paid differently for both, analytic/interactive and routine tasks. Second, the share of HE employees in an occupation has a stronger positive effect on VET graduates with an Abitur than on those without. Given that all our cross-level interactions were insignificant and that identifying significant cross-level interactions is challenging at all, calls for further research. A more comprehensive modelling of the cross-level interactions with a larger sample size (cf. Mathieu et al. 2012) could be a fruitful way to determine how wage returns vary by occupational characteristics.

In addition, we are aware that other occupational characteristics, such as unionization and social closure, may drive wage inequalities between our study groups, requiring further investigations. We derive theoretical arguments on why VET graduates with an Abitur may perform more analytic as well as interactive tasks and are more productive in doing so, but empirical proof is still pending. We concentrated our analyses on the current occupation, without additionally examining the match between employee training and current occupation, which could partly account for the revealed wage variance. Further research should explore the link between occupation-specific wage returns and this match between training and occupation. Ideally, to provide a benchmark of the wage premium from investing in an Abitur in combination with a VET degree, we need further investigations of the occupation-specific wage returns of employees with a higher education degree.

\section{Supplementary Information}

The online version contains supplementary material available at https://doi.org/10.1186/s40461-021-00111-5.

Additional file 1. Technical report: Occupational mapping and data preparation; full results.

Abbreviations

BIBB: Federal Institute for Vocational Education and Training; BAuA: Federal Institute for Occupational Safety and Health; EGP: Erikson-Goldthorpe-Portocarero-Scheme; H: Hypothesis; HCT: Human capital theory; HE degree: Higher education degree; I-as-OM: Intercept-as-outcome model; KIdB 2010: German Classification of Occupations 2010; RCM: Random coefficient model; RIRSM: Random-intercept/random-slope model; VET: Vocational education and training; VET1: VET degree without an Abitur; VET2: VET degree with an Abitur.

\section{Acknowledgements}

An earlier version of this paper was presented at the 2nd BIBB Conference on the Economics of Vocational Education and Training: Markets - Institutions - Systems, November 2019 in Siegburg. The authors would like to thank the participants for their helpful comments and suggestions. We further thank our colleagues Anja Hall, Daniela Rohrbach-Schmidt and Ana Santiago Vela for their very helpful comments on our manuscript. Last but not least, the authors are grateful for the constructive feedback of the two anonymous reviewers, which significantly contributed to the improvement of the article.

Authors' contributions

Both authors have written the manuscript in equal parts and contributed to the design and implementation of the research, to the analysis of the results and to the writing of the manuscript. Both authors read and approved the final manuscript. 


\section{Funding}

Not applicable.

\section{Availability of data and materials}

This paper uses data from the BIBB/BAuA Employment Survey of the Working Population on Qualification and Working Conditions in Germany 2018, https://doi.org/10.7803/501.18.1.1.10. The Survey was conducted by the Federal Institute for Vocational Education and Training (BIBB) and the Federal Institute for Occupational Safety and Health (BAuA). The data access is provided via a Scientific-Use-File of the Data Research Centre at the Federal Institute for Vocational Training and Education (BIBB-FDZ).

\section{Competing interests}

The authors declare that they have no competing interests.

Received: 3 December 2019 Accepted: 28 January 2021

Published online: 20 February 2021

\section{References}

Acemoglu D, Autor D (2011) Skills, tasks and technologies: Implications for employment and earnings. Handbook of Labor Economics 4:1043-1171. https://doi.org/10.1016/S0169-7218(11)02410

Alda H, Friedrich A, Rohrbach-Schmidt D (2020) Educational expansion and educational wage premiums of young male employees: A long-term analysis for West Germany 1976-2010. Soc Sci Res 85:1-23. https://doi.org/10.1016/j.ssres earch.2019.102351

Allmendinger J (1989) Educational Systems and Labor Market Outcomes. Eur Sociol Rev 5(3):231-250. https://doi. org/10.1093/oxfordjournals.esr.a036524

Antonczyk D, DeLeire T, Fitzenberger B (2018) Polarization and rising wage inequality: comparing the US and Germany. Econometrics 6(2):20. https://doi.org/10.3390/econometrics6020020

Autor D (2013) The "task approach" to labor markets: an overview. J Labour Market Res 46(3):185-199. https://doi. org/10.1007/s12651-013-0128-z

Autor D, Handel MJ (2013) Putting Tasks to the Test: Human Capital, Job Tasks, and Wages. J Lab Econ 31 (2):59-96. https:// doi.org/10.1086/669332

Autor DH, Levy F, Murnane RJ (2003) The skill content of recent technological change: an empirical exploration. Quart J Econ 118(4):1279-1333. https://doi.org/10.1162/003355303322552801

Autorengruppe Bildungsberichterstattung (2018) Bildung in Deutschland 2018 - Ein indikatorengestützter Bericht mit einer Analyse zu Wirkungen und Erträgen von Bildung. wbv Publikation, Bielefeld. https://doi.org/10.3278/6001820fw

Bachmann R, Cim M, Green C (2018) Long-Run Patterns of Labour Market Polarization: Evidence from German Micro Data. Brit J Ind Relat 57(2):350-376. https://doi.org/10.1111/bjir.12419

Barone C, van de Werfhorst HG (2011) Education, cognitive skills and earnings in comparative perspective. Int Sociol 26(4):483-502. https://doi.org/10.1177/0268580910393045

Becker GS (1964) Human Capital: A Theoretical and Empirical Analysis with Special Reference to Education. National Bureau of Economic Research, New York

Beicht U, Walden G (2018) Neue Bildungsexpansion und Verdrängungseffekte in der betrieblichen Ausbildung. Sozialer Fortschritt 67(3):141-172. https://doi.org/10.3790/sfo.67.3.141

Bellmann L, Janik F (2010) Abitur and What Next? Reasons for Gaining Double Qualifications in Germany. Schmollers Jahr 130(1):1-18. https://doi.org/10.3790/schm.130.1.1

Blau FD, Kahn LM (2017) The gender wage gap: Extent, trends, and explanations. J Econ Lit 55(3):789-865. https://doi. org/10.1257/jel.20160995

Blien U, Phan thi Hong V, (2010) Berufliche Lohnunterschiede. In: Euler D, Walwei U, Weiß R (eds) Berufsforschung für eine moderne Berufsbildung-Stand und Perspektiven. Franz Steiner Verlag, Stuttgart, pp 263-280

Bol T, van de Werfhorst HG (2011) Signals and closure by degrees: The education effect across 15 European countries. Research in Social Stratification and Mobility 29(1):119-132. https://doi.org/10.1016/j.rssm.2010.12.002

Bol T, Weeden KA (2015) Occupational closure and wage inequality in Germany and the United Kingdom. Eur Sociol Rev 31(3):354-369. https://doi.org/10.1093/esr/jcu095

Brzinsky-Fay C, Ebner C, Seibert H (2016) Veränderte Kontinuität. KZfSS Kölner Zeitschrift für Soziologie und Sozialpsychologie 68(2):229-258. https://doi.org/10.1007/s11577-016-0358-5

Bundesinstitut für Berufsbildung (BIBB) (2019) Datenreport zum Berufsbildungsbericht 2018 - Informationen und Analysen zur Entwicklung der beruflichen Bildung. Verlag Barbara Budrich, Bonn

Busch A (2013) Der Einfluss der beruflichen Geschlechtersegregation auf den „Gender Pay Gap". KZfSS 65(2):301-338. https://doi.org/10.1007/s11577-013-0201-1

Collins R (1979) The Credential Society: An Historical Sociology of Education and Stratification, vol 2. Academic Press, New York

Coulter PB (2019) Measuring inequality: A methodological handbook. Routledge, New York. https://doi. org/10.4324/9780429042874

Eggenberger C, Rinawi M, Backes-Gellner U (2018) Occupational Specificity: A new Measurement Based on Training Curricula and its Effect on Labor Market Outcomes. Lab Econ 51:97-107. https://doi.org/10.1016/j.labeco.2017.11.010

Finke C, Dumpert F, Beck M (2017) Verdienstunterschiede zwischen Männern und Frauen: eine Ursachenanalyse auf Grundlage der Verdienststrukturerhebung 2014. WISTA Wirtschaft und Statistik 2:43-62

Forster AG, Bol T (2018) Vocational education and employment over the life course using a new measure of occupational specificity. Soc Sci Res 70:176-197. https://doi.org/10.1016/j.ssresearch.2017.11.004 
Friedrich A, Horn S (2018) Qualifikatorische Bildungsrenditen in verschiedenen Datenquellen. Wissenschaftliche Diskussionspapiere 197

Geel R, Mure J, Backes-Gellner U (2011) Specificity of occupational training and occupational mobility: an empirical study based on Lazear's skill-weights approach. Educ Econ 19(5):519-535. https://doi.org/10.1080/09645291003726483

Giesecke J, Verwiebe R (2009) The changing wage distribution in Germany between 1985 and 2006. Schmollers Jahrbuch 129(2):191-201

Göggel K, ZwickT (2012) Heterogeneous Wage Effects of Apprenticeship Training. Scand J of Economics 114(3):756-779. https://doi.org/10.1111/j.1467-9442.2012.01712.x

Hall A (2012) Lohnen sich schulische und duale Ausbildung gleichermassen? Bildungserträge von Frauen und Männern im Vergleich. In: Becker R, Solga H (eds) Kölner Zeitschrift für Soziologie und Sozialpsychologie. Soziologische Bildungsforschung. Sonderheft 52. Springer Fachmedien, Wiesbaden, pp 281-301. https://doi.org/10.1007/978-3658-00120-9_12

Hall A, Siefer A, Tiemann M (2020) BIBB/BAuA Employment Survey of the Working Population on Qualification and Working Conditions in Germany 2018 suf_1.0 edn. Research Data Center at BIBB; GESIS Cologne (data access), Bonn: Federal Institute for Vocational Education and Training. https://doi.org/10.7803/501.18.1.1.10

Haupt A (2016a) Erhöhen berufliche Lizenzen Verdienste und die Verdienstungleichheit? Zeitschrift für Soziologie 45(1):39-56. https://doi.org/10.1515/zfsoz-2015-1002

Haupt A (2016b) Zugang zu Berufen und Lohnungleichheit in Deutschland. Springer, Wiesbaden. https://doi. org/10.1007/978-3-658-11296-7

Haupt A, Ebner C (2020) Occupations and Inequality: Theoretical Perspectives and Mechanisms. Kzfss. 72(1):19-40. https ://doi.org/10.1007/s11577-020-00685-0

Hinz T, Gartner H (2005) Geschlechtsspezifische Lohnunterschiede in Branchen. Berufen und Betrieben Zeitschrift für Soziologie 34(1):22-39

Jacob M, Steininger H-M, Weiss F (2013) Bleibt's dabei? Soziale Ungleichheiten in der Studienabsicht und ihrer Realisierung nach einer beruflichen Ausbildung. In: Asdonk J, Kuhnen SU, Bornkessel P (eds) Von der Schule zur Hochschule: Analysen, Konzeptionen und Gestaltungsperspektiven des Übergangs. Waxmann, Münster, pp 307-322

Kleinert C, Jacob M (2012) Strukturwandel des Übergangs in eine berufliche Ausbildung. In: Becker R, Solga H (eds) Kölner Zeitschrift für Soziologie und Sozialpsychologie. Soziologische Bildungsforschung. Sonderheft 52. Springer Fachmedien, Wiesbaden, pp 211-233. https://doi.org/10.1007/978-3-658-00120-9_9

Langer W (2010) Mehrebenenanalyse mit Querschnittsdaten. In: Wolf C, Best H (eds) Handbuch der sozialwissenschaftlichen Datenanalyse. VS Verlag für Sozialwissenschaften, Wiesbaden, pp 741-774. https://doi.org/10.1007/978-3-53192038-2

Lazear EP (2009) Firm-specific human capital: A skill-weights approach. J Polit Economy 117(5):914-940. https://doi. org/10.1086/648671

Mathieu JE, Aguinis H, Culpepper SA, Chen G (2012) Understanding and estimating the power to detect cross-level interaction effects in multilevel modeling. J Appl Psychol 97(5):951. https://doi.org/10.1037/a0028380

Müller W, Lüttinger P, König W, Karle W (2003) Class and Education in Industrial Nations. Int J Sociology 19(3):3-39. https ://doi.org/10.1080/15579336.1989.11769981

Pilz M (2009a) After Abitur, First an Apprenticeship and then University? Why German Abitur Holders Are Taking Vocational Training in the Financial Services Sector. European Journal of vocational training 46(1):41-65

Pilz M (2009b) Why Abiturienten do an apprenticeship before going to university: the role of 'double qualifications' in Germany. Oxf Rev Educ 35(2):187-204. https://doi.org/10.1080/03054980902771072

Piopiunik M, Schwerdt G, Simon L, Woessmann L (2020) Skills, signals, and employability: An experimental investigation. Europ Econ Rev 123:103374. https://doi.org/10.1016/j.euroecorev.2020.103374

Powell J, Solga H (2011) Why are higher education participation rates in Germany so low? Institutional barriers to higher education expansion. J Education and Work 24(1-2):49-68. https://doi.org/10.1080/13639080.2010.534445

Protsch P, Solga H (2015) The social stratification of the German VET system. J Education and Work 29(6):637-661

Rabe-Hesketh S, Skrondal A (2012) Multilevel and longitudinal modeling using Stata. Stata press, College Station, Texas

Reiss K, Weis M, Klieme E, Köller O (2019) PISA 2018: Grundbildung im internationalen Vergleich. Waxmann Verlag, Münster. https://doi.org/10.31244/9783830991007

Rohrbach-Schmidt D (2019) Putting tasks to the test: The case of Germany. Social Inclusion 7(3):122-135. https://doi. org/10.17645/si.v7i3.2025

Rohrbach-Schmidt D, Hall A (2020) BIBB/BAuA Employment Survey 2018. BIBB-FDZ Data and Methodological Reports $1 / 2020$

Rohrbach-Schmidt D, Tiemann M (2013) Changes in workplace tasks in Germany_evaluating skill and task measures. J Labour Market Res 46(3):215-237. https://doi.org/10.1007/s12651-013-0140-3

Schneider SL (2008) The International Standard Classification of Education (ISCED-97). An Ecaluation of Content and Criterion Validity for 15 European Countries. Mannheimer Zentrum für europäische Sozialforschung, Mannheim.

Spence M (1973) Job market signaling Quart J Econ 87(3):355-374

Stüber H (2016) Berufsspezifische Lebensentgelte: Qualifikation zahlt sich aus. IAB-Kurzbericht 17|2016

Thurow LC (1975) Generating inequlity Basic Books, New York.

Tuor SN, Backes-Gellner U (2010) Risk-return trade-offs to different educational paths: vocational, academic and mixed. Int J Manpower 31 (5):495-519. https://doi.org/10.1108/01437721011066335

Wrohlich K, Zucco A (2017) Gender pay gap varies greatly by occupation. DIW Economic Bulletin 7(43):429-435

\section{Publisher's Note}

Springer Nature remains neutral with regard to jurisdictional claims in published maps and institutional affiliations. 